\title{
(RE)DESCOBRINDO UMA HISTÓRIA NÃO CELEBRADA PELA CIÊNCIA
}

Cristiane Biazzin Villar cristianevillar@hotmail.com

Doutoranda em Administração de Empresas pela Escola de Administração de Empresas de São Paulo, Fundação Getulio Vargas

- São Paulo - SP, Brasil

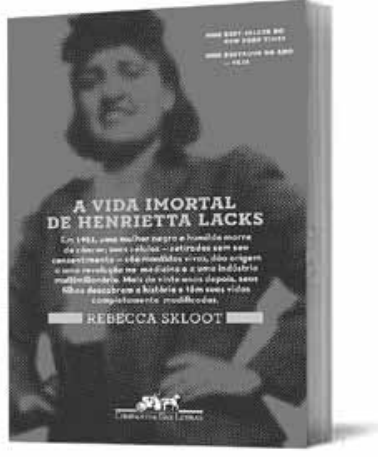

\section{A VIDA IMORTAL DE HENRIETTA LACKS}

Rebecca Skloot. São Paulo:

Companhia das Letras, 2011. 454 p.

As questões éticas em pesquisa têm sido alvo constante de discussão na academia e na mídia, além de fazerem parte da prática diária de qualquer pesquisador. Rebecca Skloot pesquisou durante 10 anos a história de Henrietta Lacks, uma jovem de 31 anos que faleceu em 1951, vítima de câncer do colo do útero. Isso talvez não tivesse tanta relevância se não fossem dois fatos importantes: o primeiro é que as células de Henrietta geraram as células HeLa, as primeiras células humanas mantidas em cultura e vivas até hoje, e que deram origem a uma revolução na medicina e a uma indústria multibilionária. O segundo é o fato de Henrietta ser negra e humilde e de que as células cancerosas foram extraídas sem consentimento ou conhecimento, seu ou de sua família. Naquela época, era comum a utilização de pacientes de enfermarias públicas sem seu conhecimento para pesquisas, quando diversos pesquisadores acreditavam que, por esses pacientes terem acesso a exames, seria justo usá-los como cobaias para experimentos.

A obra começa com a apresentação da autora, uma jornalista científica, e suas motivações para o desenvolvimento da pesquisa. A autora tomou conhecimento das células HeLa e do grande impacto que causara na medicina ainda na adolescência, porém pouco se sabia sobre suas origens, apenas que eram de uma mulher negra e que haviam sido coletadas nos anos 1950. Durante os anos seguintes, Rebecca, aos poucos, foi colecionando informações a respeito, até que, no final dos anos 1990, decidiu con- tatar os familiares de Henrietta em Baltimore. A autora não imaginava que aquela ligação telefônica seria o marco inicial de uma trajetória de uma década por laboratórios científicos, hospitais, instituições psiquiátricas, com um grande elenco de personagens. Por conta da ânsia de buscar respostas sobre a origem da cultura de células e do embate ético que a cerceava, Rebecca percebeu que lentamente (e por conta do tempo de imersão) acabou tornando-se parte daquela história.

O livro faz paralelos entre a história de Henrietta, principalmente seus últimos dias de vida, e a história dos cientistas que ansiavam por encontrar uma forma de cultivar células, a evolução da biomedicina e a própria saga da escritora em coletar os dados para sua pesquisa.

Dr. George Gey desenvolveu com sua equipe a metodologia de cultura, tipo adequado de esterilização e construiu pessoalmente todo o laboratório à mão (quase tudo utilizando sucata, devido a sua dificuldade de recursos). Foi ele quem recebeu as células de Henrietta, coletadas durante um procedimento cirúrgico para a retirada de um tumor em seu útero, e conseguiu, com 
sua equipe, mantê-las vivas. Depois da descoberta da cultura das células e de sua incrível multiplicação, Dr. Gey começou a compartilhar essas células com qualquer cientista que tivesse interesse. Uma das primeiras aplicações das células HeLa foi nos testes da vacina contra a poliomielite, pois, nesse mesmo ano, o mundo vivia a maior epidemia da história e ansiava-se por uma vacina. A vacina fora descoberta havia pouco por Jonas Salk, e sua aplicação em crianças só poderia ser oferecida depois de testada em grande escala, pois, caso funcionasse, o soro bloquearia o vírus e protegeria as células. Caso contrário, o vírus infectaria as células e a criança seria contaminada. Os testes nas células HeLa foram um sucesso e, em pouco tempo, a vacina foi distribuída à população.

Pesquisadores começaram, então, a utilizá-las nos mais variados tipos de experimentos: expondo-as a vírus, contribuindo para um avanço imensurável no campo da virologia; posteriormente, submetendo-as a processos de congelamento, nos quais as mais diversas etapas poderiam ser mapeadas durante o processo de multiplicação celular, por exemplo, a identificação exata do número de cromossomos, contribuindo para detecção de distúrbios como síndrome de Down. Além disso, as células foram submetidas a alta radiação, para analisar os impactos de bombas nucleares, e a pressão, para compreender o impacto em condições extremas de mergulho subaquático ou voos espaciais. Testaram efeitos de esteroides, remédios quimioterápicos, hormônios, vitaminas, estresse ambiental e fizeram os primeiros exercícios de clonagem celular.

A obra apresenta interessantes detalhes sobre a evolução da pesquisa e da medicina, ressaltando alguns atos bizarros dos cientistas da época. Na verdade, nos anos
1950, pouco havia se definido em questões éticas da ciência. Naquela época, não havia regulamentação ou supervisão formal das pesquisas nos Estados Unidos. Tentativas de regulamentação eram seguidas de protestos de médicos e pesquisadores, dizendo que interfeririam no "desenvolvimento da ciência". Em 1947, sete médicos nazistas foram condenados em um Tribunal de Guerra por conduzirem pesquisas inescrupulosas em judeus sem seu consentimento. Daí surgiu o Código de Nuremberg, que, apesar de não ter força de lei, direcionaria todos os experimentos em seres humanos no mundo, trazendo a ideia revolucionária de que o consentimento voluntário do ser humano em participar do experimento era absolutamente essencial e que o paciente deveria ter acesso aos fatos necessários para a decisão.

A família Lacks, no entanto, só tomou ciência da coleta das células de Henrietta 20 anos após sua morte, por conta de um artigo publicado em tributo ao cientista George Gey. Para a família, tratava-se de uma possível imortalidade de Henrietta, e essa ideia os aterrorizou. Por conta da falta de esclarecimento, a família acabou construindo suas próprias teorias quanto à imortalidade das células HeLa, uma mistura de valores morais e religiosos. Atualmente há, até certo ponto, controle das patentes dos materiais biológicos (de propriedade de cientistas, empresas farmacêuticas, universidades) que regulam sua aplicabilidade, mas ainda existe a polêmica quanto à remuneração dos doadores.

O trabalho de Rebecca Skloot é emocionante e envolvente, destacando-se pela preocupação em captar e manter a linguagem dos entrevistados, toda riqueza e sutilezas percebidas nos documentos, fotos, cartas, diários, prontuários médicos e artigos.
A obra traz à tona não apenas uma discussão sobre a polêmica dos experimentos científicos em humanos e da comercialização de material biológico, mas também sobre as questões de gênero, raça, valores, fé, tão presentes durante o processo da pesquisa, inclusive nos estudos organizacionais. Nesse contexto, entre os diversos autores, destaca-se o trabalho de Alcadipani e Rosa (RAE, v. 50, n. 4, out.-dez. 2010, O Pesquisador Como o Outro: uma Leitura Pós-colonial do "Borat" Brasileiro), que relata como as hierarquias sociais podem manifestar-se na prática da pesquisa científica nas organizações, reiterando a dificuldade de articular a dicotomia sujeito-objeto. De fato, apesar de os códigos de conduta favorecerem novas formas de reflexão sobre a pesquisa científica em administração, como discutido no livro de Bryman e Bell (Business Research Methods, 2. ed., Oxford, 2007), Steven J. Taylor (Qualitative Sociology, v. 10, n. 3, 1987, Observing Abuse: Professional Ethics and Personal Morality in Field Research), ressalta a impossibilidade da codificação das questões éticas e morais de maneira completa, logo espera-se que o pesquisador seja capaz de balancear as obrigações com a profissão, com a sociedade, com o desenvolvimento do conhecimento e, acima de tudo, com as pessoas estudadas.

Em suma, a obra de Skloot incita a reflexão sobre alguns princípios fundamentais que direcionam a integridade da pesquisa científica, como um alerta para a observação criteriosa do papel do pesquisador e a proteção dos participantes de pesquisas científicas, poupando-os de qualquer dano indevido e, consequentemente, mantendo a responsabilidade e autonomia do pesquisador no desenvolvimento dos estudos. 